\title{
Enzyme activity by different isolates of $E$. chrysanthemi in Aloe vera
}

\section{SYAMALA}

Department of Plant Pathology, Agricultural College and Research Institute, Tamil Nadu Agricultural University, COIMBATORE (T.N.) INDIA

\section{ARITCLE INFO}

Received : 01.07 .2017

Revised : 03.09.2017

Accepted : 15.09 .2017

Email :ms_shayamala@yahoo.co.in

\begin{abstract}
:
Aloe vera soft rot disease, which also induced activity of Pectate lyase activity, Pectin methyl esterase, Polygalacturonase, pectin trans eliminase activity. The enzyme activity of inoculated aloe plants increased from the two day till the six DAI and slowly declined thereafter in all the 15 isolates.
\end{abstract}

How to view point the article : Syamala, M. (2017). Enzyme activity by different isolates of $E$. chrysanthemi in Aloe vera . Internat. J. Plant Protec., 10(2) : 393-398, DOI : 10.15740/HAS/ IJPP/10.2/393-398.

KEY WORDS : Soft rot, Pectate lyase activity, Pectin methyl esterase, Polygalacturonase, Pectin trans eliminase activity, Aloe vera 